Article

\title{
Hydrochemical Characteristics and Multivariate Statistical Analysis of Natural Water System: A Case Study in Kangding County, Southwestern China
}

\author{
Yunhui Zhang ${ }^{1}{ }^{\mathbb{D}}$, Mo Xu ${ }^{1, *}$, Xiao Li ${ }^{1, *}$, Jihong $\mathrm{Qi}^{1}{ }^{1}$, Qiang Zhang ${ }^{1}$, Jian Guo ${ }^{1}$, Leilei Yu ${ }^{2}$ \\ and Rui Zhao ${ }^{3}$ \\ 1 State Key Laboratory of Geohazard Prevention and Geoenvironment Protection, Chengdu University of \\ Technology, Chengdu 610059, China; zhangyunhui0710@163.com (Y.Z.); qijihong@cdut.edu.cn (J.Q.); \\ zhangq@cdut.edu.cn (Q.Z.); guojian2014@cdut.edu.cn (J.G.) \\ 2 Guangxi Communications Planning Surveying and Designing Institute Co., Ltd., Nanning 530029, China; \\ yull18376998769@163.com \\ 3 School of Energy and Power engineering, Xihua University, Chengdu 610039, China; \\ zrcc118@mail.xhu.edu.cn \\ * Correspondence: XM@cdut.edu.cn (M.X.); lixiao@cdut.edu.cn (X.L.); \\ Tel.: +86-138-081-99827 (M.X.); +86-138-080-36812 (X.L.)
}

Received: 16 November 2017; Accepted: 11 January 2018; Published: 19 January 2018

\begin{abstract}
The utilization for water resource has been of great concern to human life. To assess the natural water system in Kangding County, the integrated methods of hydrochemical analysis, multivariate statistics and geochemical modelling were conducted on surface water, groundwater, and thermal water samples. Surface water and groundwater were dominated by $\mathrm{Ca}-\mathrm{HCO}_{3}$ type, while thermal water belonged to $\mathrm{Ca}-\mathrm{HCO}_{3}$ and $\mathrm{Na}-\mathrm{Cl}-\mathrm{SO}_{4}$ types. The analyzing results concluded the driving factors that affect hydrochemical components. Following the results of the combined assessments, hydrochemical process was controlled by the dissolution of carbonate and silicate minerals with slight influence from anthropogenic activity. The mixing model of groundwater and thermal water was calculated using silica-enthalpy method, yielding cold-water fraction of 0.56-0.79 and an estimated reservoir temperature of $130-199{ }^{\circ} \mathrm{C}$, respectively. $\delta \mathrm{D}$ and $\delta^{18} \mathrm{O}$ isotopes suggested that surface water, groundwater and thermal springs were of meteoric origin. Thermal water should have deep circulation through the Xianshuihe fault zone, while groundwater flows through secondary fractures where it recharges with thermal water. Those analytical results were used to construct a hydrological conceptual model, providing a better understanding of the natural water system in Kangding County.
\end{abstract}

Keywords: hydrochemical characteristics; water-rock interaction; multivariate statistical analysis; mixing model; $\delta \mathrm{D}$ and $\delta^{18} \mathrm{O}$ isotopes; natural water system; Kangding County

\section{Introduction}

Water is an incredibly important resource, and has significant uses in agriculture, industry and domestic use. To better utilize it, a number of studies have been conducted to assess water quality [1-4]. Water quality is determined by the hydrochemistry affected by different hydrochemical processes. Furthermore, hydrochemical processes are determined by natural physical-chemical activities, e.g., ion exchange, mineral dissolution and precipitation, water-rock interaction, and redox transformation [5-7].

To date, hydrochemical analysis [8,9], multivariate statistical analysis [10,11], and geochemical modelling $[12,13]$ have proven to be efficient for constraining the hydrochemical process of natural 
water systems. The ratios of major ions provide critical clues to explain different hydrochemical processes of water resource [14,15]. Principle component analysis (PCA) is useful for analyzing the large hydrochemical dataset, defining the factors controlling hydrochemistry $[16,17]$. Geochemical modelling using saturation index can specify mineral precipitation and dissolution in natural water system $[18,19] . \delta \mathrm{D}$ and $\delta^{18} \mathrm{O}$ isotopes are ideal tracers for the source and pathways of groundwater recharge [20-22].

Southwestern China is well-known for its abundant water resource, including the Dadu River, Jinsha River and Nu River. The Kangding County is located in southwestern China, and dominated by the Dadu River. However, previous studies were mainly focused on the genesis of thermal water in Kangding County. Qi et al. (2017) achieved a preliminary knowledge of thermal water and discussed the relationship between changing parameters of thermal water and solid tide [23]. Luo et al. (2017) compared the thermal springs in northern and southern Kangding County and evaluated their exploratory potential [24]. Guo et al. (2017) investigated the high-temperature geothermal system using fluid and gas geochemistry [25]. Compared with thermal water, very little knowledge has been achieved on the chemical components of surface water and groundwater and related hydrochemical processes. Moreover, the mixing model between groundwater and thermal water is enigmatic, and has yet to be constrained.

In this study, we investigated the occurrence of fractures, interpreted hydrochemical characteristics, and conducted $\delta \mathrm{D}$ and $\delta^{18} \mathrm{O}$ isotopic analysis for surface water, groundwater, and thermal water. Then, we attempted to obtain deeper knowledge of the hydrochemical process based on correlations of major ions, PCA analysis and geochemical modelling. Furthermore, the mixing ratio between groundwater and thermal water was evaluated by the silica-enthalpy method. The recharge area of surface water, groundwater, and thermal water was identified by $\delta \mathrm{D}$ and $\delta^{18} \mathrm{O}$ isotopes. Those analytical results would be helpful to build a hydrological conceptual model for natural water system, providing valuable information for better exploiting water resource in Kangding County.

\section{Geological Setting}

Kangding County is situated in the Sichuan Province, southwestern China. Tectonically, it is located in the eastern margin of Tibet Plateau where three regional fault zones (Xianshuihe (XSF), Anninghe (ANF) and Longmenshan (LMF) fault zones) formed a Y-shape intersection (Figure 1a).

The altitude of Kangding County is generally higher than $1000 \mathrm{~m}$, with the highest elevation of $7556 \mathrm{~m}$ (Mount. Gongga). Due to the high-mountain topography and barren environment, anthropogenic activity is rare here. Based on the local meteorological data, annual precipitation and relative humidity are 500-800 $\mathrm{mm}$ and $73 \%$, respectively. Annual temperatures range from -14.1 to $29.4{ }^{\circ} \mathrm{C}$ (mean $\left.=7.1{ }^{\circ} \mathrm{C}\right)$.

The study area is located in the southern segment of Kangding County. The bedrocks consist of Devonian, Permian, and Triassic sedimentary strata (Figures $1 b$ and 2a). Devonian strata exposed in the south are composed of limestone and mudstone; Permian strata crop in the west and are subdivided into upper and lower Permian strata, consisting of limestone and sandstone; Triassic strata are scarcely distributed in the middle part, dominated by sandstone. Quaternary sediments are locally exposed, including boulder and sandy gravel. Multi-episode magmatic rocks include the Proterozoic granites in the east and Cenozoic granites in the west [26] (Figure 1b). The structures are dominated by the $\mathrm{N}-\mathrm{S}$-trending Xianshuihe strike-slip fault that is locally buried by Quaternary sediments [27]. Amounts of NNE-striking secondary fractures are developed along the Xianshuihe fault (Figure 2b,c).

The Dadu River traverses southwardly through Kangding County, fed by a number of streams (Figure 1b). Fractures are extensively distributed in the Triassic sandstone and Cenozoic granite, while karst conduits are developed in the Permian limestone, representing a high permeability aquifer. The less cracked Proterozoic granite and Devonian limestone and mudstone strata represent medium permeability aquifers. Thermal springs are exposed parallel with the Xianshuihe fault, with temperatures over a range of 35 to $81^{\circ} \mathrm{C}$ (Local boiling temperature $=89.5^{\circ} \mathrm{C}$ ) [23-25] (Figure $1 \mathrm{~b}, \mathrm{c}$ ). 

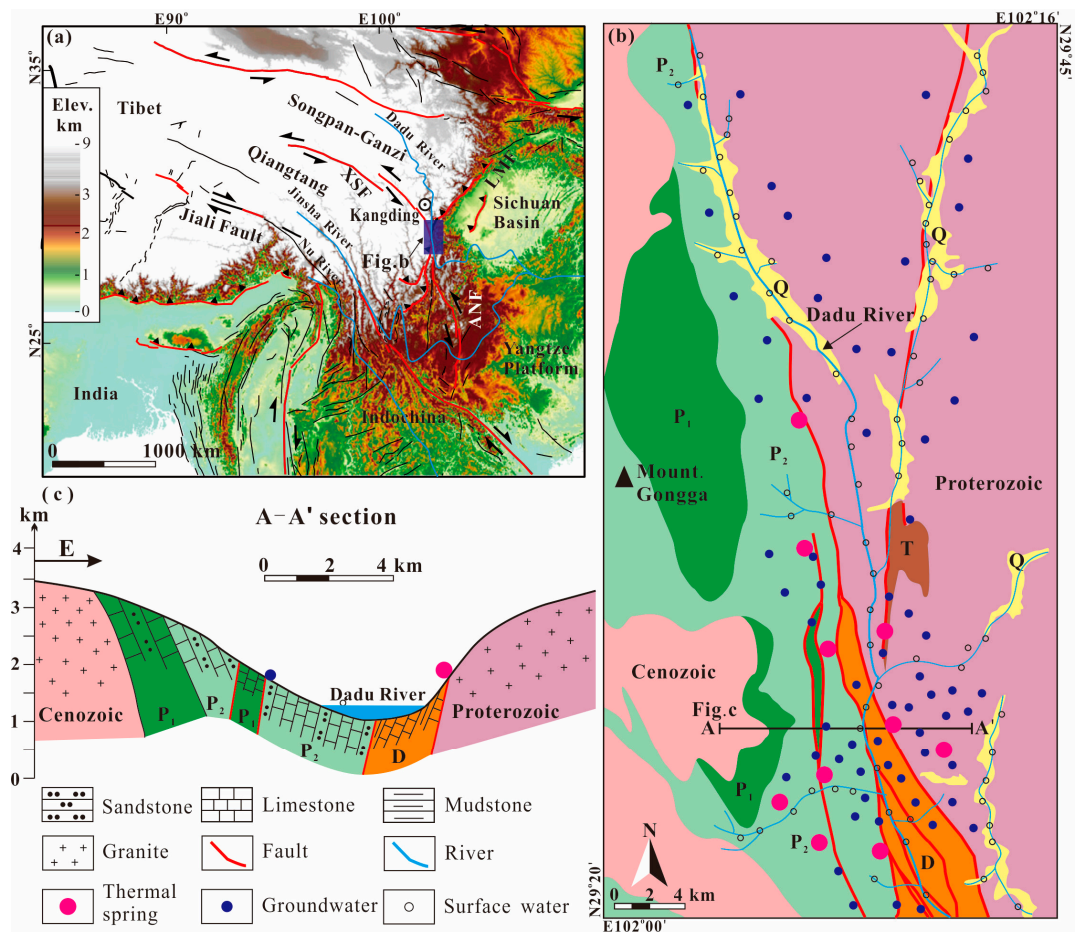

Figure 1. (a) Topography of Southwestern China; (b) geological map and (c) cross section of Kangding County. D: Devonian, $\mathrm{P}_{1}$ : Lower Permian, $\mathrm{P}_{2}$ : Upper Permian, T: Triassic, Q: Quaternary.

(a)

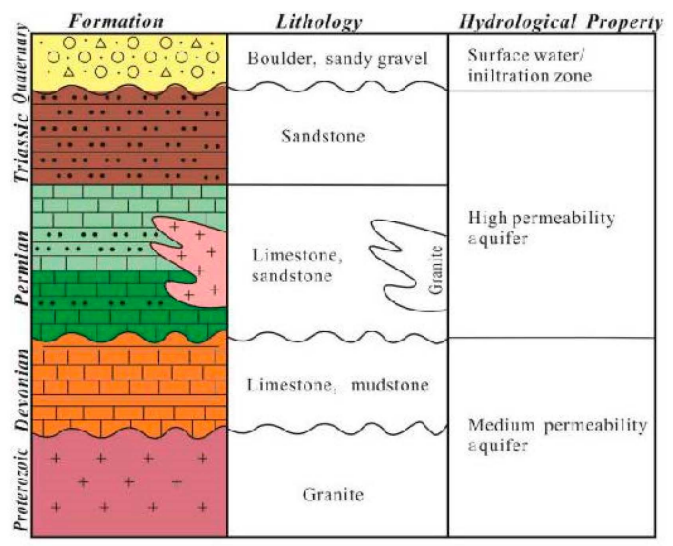

(b)

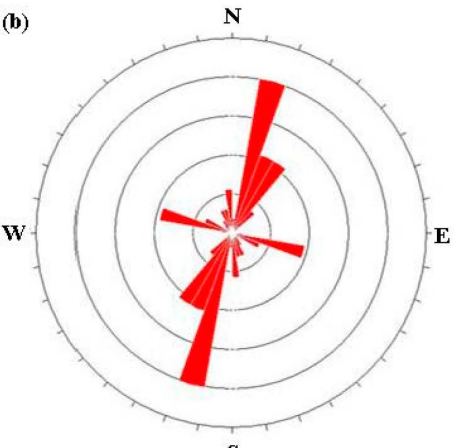

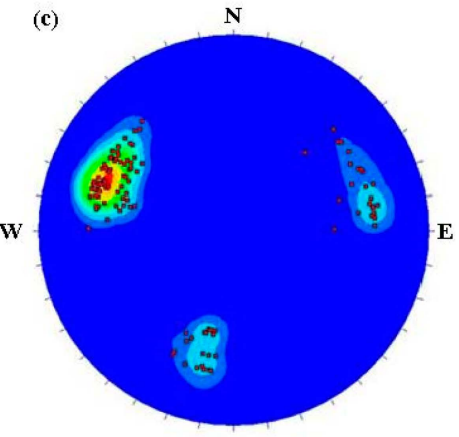

S

Figure 2. (a) Stratigraphic column showing lithology and hydrological properties; (b) Rose diagram and (c) stereographic diagrams (equal area projection, lower hemisphere) with poles and contouring of fractures in study area. Strata legends are same as Figure 1. 


\section{Sampling and Methods}

Sampling work was conducted in November and December 2012, these months being regarded as the dry season based on local meteorological record. Fifty-three groundwater samples were collected from different cold springs in field crops and fresh rock fractures in tunnels from our study area (Figure 1b). For comparison, 72 surface water samples were collected from the Dadu River and adjacent streams, while 15 rain samples were collected. Additionally, 10 thermal water samples were collected from different thermal springs. 550-mL polyethylene bottles were used to collect water samples. Prior to sampling, these bottles were washed and rinsed at least three times. Hydrochemical analysis of the water samples was performed within 10 days in the State Key Laboratory of Geohazard Prevention and Geo-environment Protection, Chengdu University of Technology. $\mathrm{HCO}_{3}{ }^{-}$was determined by Gran titration with $0.025 \mathrm{~N} \mathrm{HCl}$. Cation samples were preserved with concentrated reagent $\mathrm{HCl}$ to $\mathrm{pH}$ $<$ 1.0. Cations $\left(\mathrm{Na}^{+}, \mathrm{K}^{+}, \mathrm{Ca}^{2+}, \mathrm{Mg}^{2+}\right)$ were analyzed by Inductively Coupled Plasma Optical Emission Spectrometry (ICP-OES, ICAP6300)and anions $\left(\mathrm{Cl}^{-}, \mathrm{SO}_{4}{ }^{2-}\right)$ by DIONEX-500 ion chromatograph (ICS-1100), respectively. Quality measurement for hydrochemical data was tested by ionic balance error (better than $\pm 10 \%$, calculated by Aquachem 3.7 software). $\delta \mathrm{D}$ and $\delta^{18} \mathrm{O}$ isotopes were measured in the Institute of Karst Geology, Chinese Academy of Geological Science, using a mass spectrometer (MAT253). The $\delta \mathrm{D}$ and $\delta^{18} \mathrm{O}$ analytical precision was better than $1 \%$ and $0.1 \%$, respectively.

Phreeqc 3 software was applied to calculate saturation index (SI), based on the MINTEQ database [28]. The SI values of major minerals, containing calcite, dolomite, gypsum, and halite, were calculated to evaluate the chemical equilibrium between minerals and water in nature environment.

Multivariate statistical analysis was carried out using SPSS 20 software. The correlation matrix based on the Pearson's correlation coefficient was used for showing relationships between those variables, with a range of values from -1 to +1 . Values close to +1 present strong positive correlation, while values approximate to -1 imply strong negative correlation. Values equal to 0 mean no linear correlation. Principle Component Analysis (PCA) was conducted to analyze the relationship between the variables and evaluate the factors affecting hydrochemical components.

\section{Results and Discussion}

\subsection{Hydrochemical Characteristics of Water Samples}

Surface water (stream, river), groundwater (fractured water, cold spring), thermal water and rain samples were classified, as shown in Table S1. The Schöeller diagram for those samples is illustrated in Figure 3, indicating the variations of physicochemical parameters.

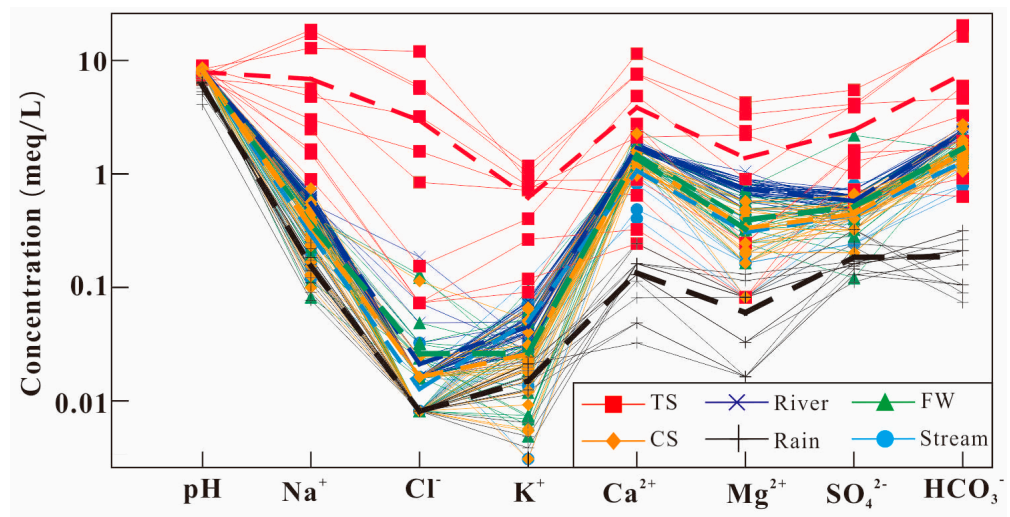

Figure 3. Schöeller diagram for different water samples (unit: meq/L). Dash lines stand for the mean values of different water samples. TS: Thermal spring, CS: Cold spring, FW: Fractured water.

The surface water and groundwater are neutral to alkaline in nature and have similar chemical compositions, whereas thermal water contains higher concentrations of major ions (Figure 3). The total 
dissolved solid (TDS) values of surface water, groundwater, and thermal water are 52.2-177.1 mg/L, 82.2-227.4 mg/L, and 104.6-1666.9 mg/L, respectively. In the most water samples, the anions are dominated by $\mathrm{HCO}_{3}{ }^{-}$with abundance order of $\mathrm{HCO}_{3}{ }^{-}>\mathrm{SO}_{4}{ }^{2-}>\mathrm{Cl}^{-}$, while the main cation is $\mathrm{Ca}^{2+}$, with abundance order of $\mathrm{Ca}^{2+}>\mathrm{Na}^{+}>\mathrm{Mg}^{2+}>\mathrm{K}^{+}$. Piper's diagram illustrates the scatter plots of the cations $\left(\mathrm{Na}^{+}+\mathrm{K}^{+}, \mathrm{Ca}^{2+}\right.$, and $\left.\mathrm{Mg}^{2+}\right)$ and anions $\left(\mathrm{HCO}_{3}{ }^{-}, \mathrm{Cl}^{-}\right.$and $\left.\mathrm{SO}_{4}{ }^{2-}\right)$, classifying the hydrochemical characteristics [29]. Herein, two main water types have been identified; most water samples were concentrated on the field of $\mathrm{Ca}^{2+}-\mathrm{HCO}_{3}{ }^{-}$, whereas a few thermal water samples were plotted on the field of $\mathrm{Na}^{+}-\mathrm{Cl}^{-}-\mathrm{SO}_{4}{ }^{2-}$ (Figure 4). The greater concentrations of major ions and higher TDS values of thermal water suggest a longer residence time and stronger water-rock interaction.

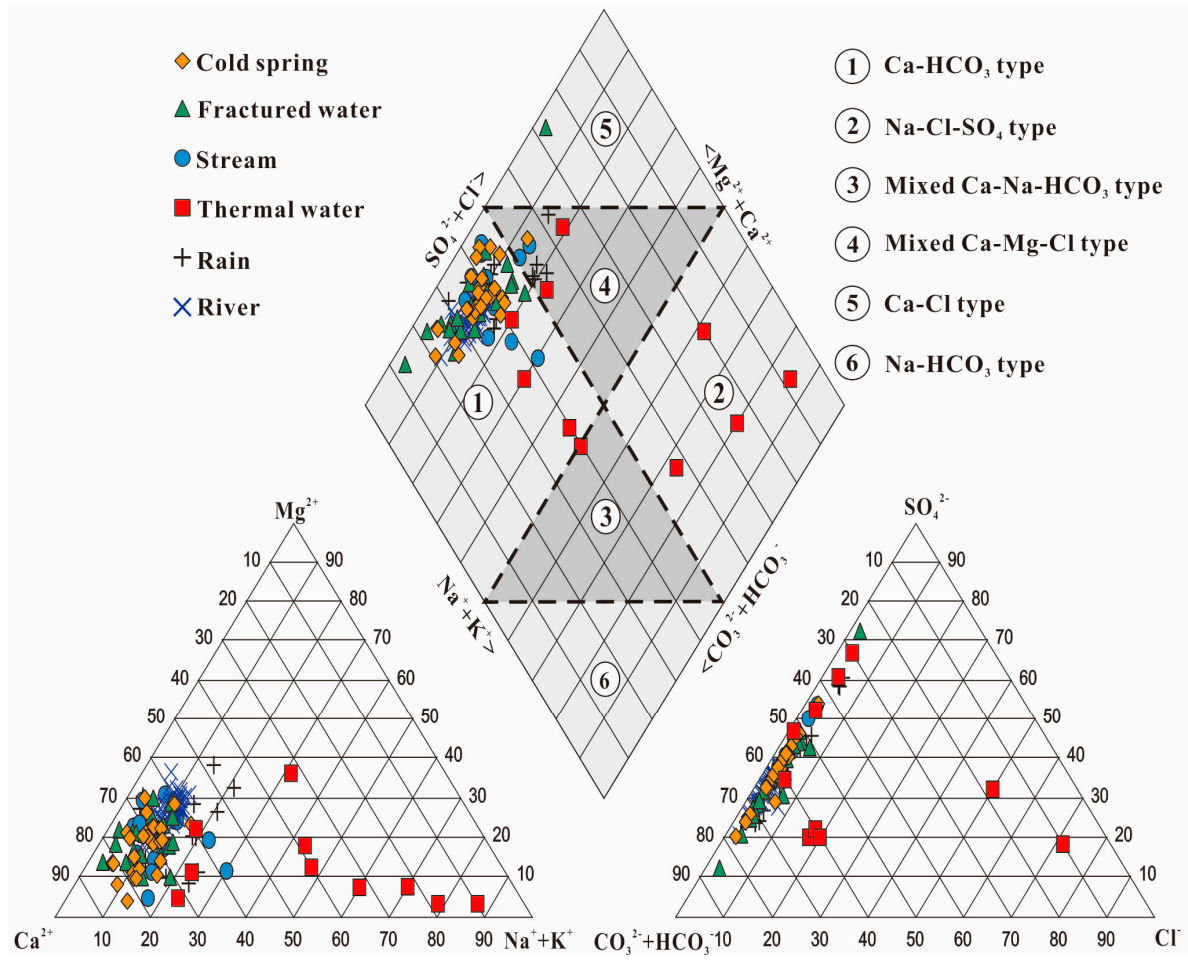

Figure 4. Piper plot of water samples.

\subsection{Hydrochemcial Process of Surface Water and Groundwater}

\subsubsection{Correlation of Major Ions}

The soluble ions of groundwater can be sourced from a variety of natural processes, such as precipitation, evaporation, and water-rock interaction. A Gibbs diagram is used to distinguish the effects of these different processes [30]. In the Gibbs TDS versus $\mathrm{Na}^{+} /\left(\mathrm{Na}^{+}+\mathrm{Ca}^{2+}\right)$ and $\mathrm{Cl}^{-} /\left(\mathrm{Cl}^{-}+\mathrm{HCO}_{3}{ }^{-}\right)$diagrams, the majority of the samples plotted in the field of rock weathering (Figure 5), indicating water-rock interaction is the main factor controlling dissolved hydrochemical components of water samples.

The concentrations of major ions and their correlation give insight to the hydrochemical process triggered by water-rock interaction [31]. Due to the major water type of $\mathrm{Ca}^{2+}-\mathrm{HCO}_{3}{ }^{-}$, the dissolution of carbonate minerals (calcite and dolomite) should be responsible for the source of $\mathrm{Ca}^{2+}$ and $\mathrm{HCO}_{3}{ }^{-}$ in water, as shown in the following Equations (1) and (2).

$$
\begin{gathered}
\mathrm{CaCO}_{3} \text { (calcite) }+\mathrm{H}_{2} \mathrm{CO}_{3} \rightarrow \mathrm{Ca}^{2+}+2 \mathrm{HCO}_{3}{ }^{-} \\
\mathrm{CaMg}\left(\mathrm{CO}_{3}\right)_{2} \text { (dolomite) }+2 \mathrm{H}_{2} \mathrm{CO}_{3} \rightarrow \mathrm{Ca}^{2+}+\mathrm{Mg}^{2+}+4 \mathrm{HCO}_{3}{ }^{-}
\end{gathered}
$$


Based on the Equations (1) and (2) above, the dissolution of calcite and dolomite would produce the $\mathrm{Ca}^{2+} / \mathrm{HCO}_{3}{ }^{-}$and $\left(\mathrm{Ca}^{2+}+\mathrm{Mg}^{2+}\right) / \mathrm{HCO}_{3}{ }^{-}$molar ratio of 0.5 . In this study, the $\mathrm{Ca}^{2+} / \mathrm{HCO}_{3}{ }^{-}$ratios of most samples were between 0.5 and 1 (Figure 6a), while $\left(\mathrm{Ca}^{2+}+\mathrm{Mg}^{2+}\right) / \mathrm{HCO}_{3}{ }^{-}$ratios were greater than 1 (Figure 6b). Hence, the excess concentrations of $\mathrm{Ca}^{2+}$ and $\mathrm{Mg}^{2+}$ should be affected by other hydrochemical processes rather than sole dissolution of carbonates (calcite and dolomite). Moreover, the $\mathrm{Ca}^{2+} / \mathrm{Mg}^{2+}$ molar ratio is used to clarify the dissolution of carbonates [3]. $\mathrm{A} \mathrm{Ca}^{2+} / \mathrm{Mg}^{2+}$ molar ratio below 1 triggers dissolution of dolomite, whereas a $\mathrm{Ca}^{2+} / \mathrm{Mg}^{2+}$ molar ratio higher than 1 indicates the dissolution of calcite. Additionally, a $\mathrm{Ca}^{2+} / \mathrm{Mg}^{2+}$ molar ratio greater than 2 can be the result of the dissolution of silicate minerals. Most samples had $\mathrm{Ca}^{2+} / \mathrm{Mg}^{2+}$ molar ratios largely greater than 2 in this study. Therefore, we can infer $\mathrm{Ca}^{2+}$ concentration should be affected by the dissolution of silicate minerals as well.
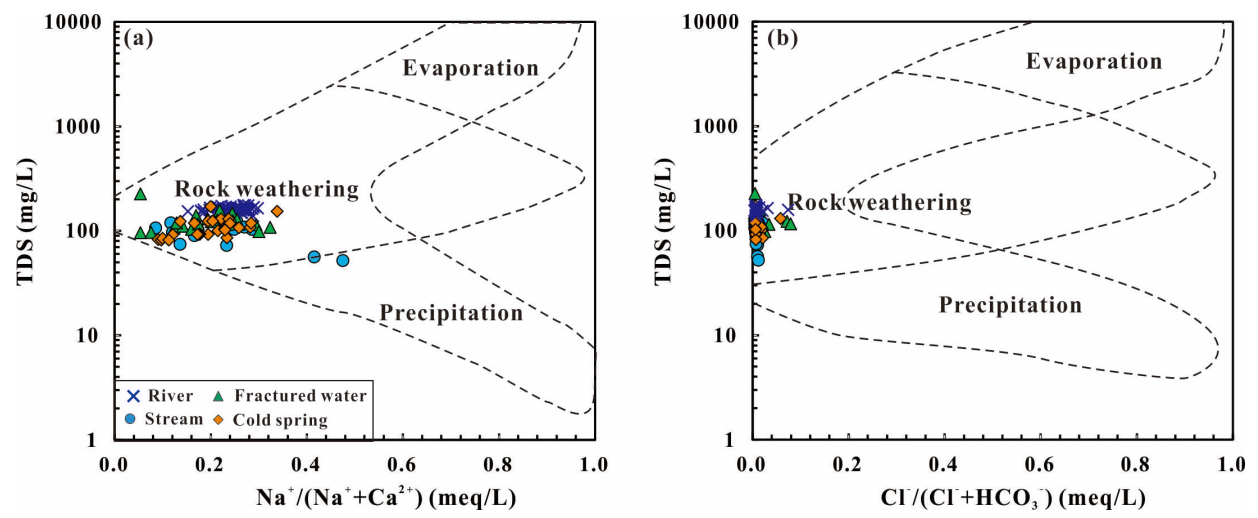

Figure 5. Gibbs plot. (a) Total dissolved solids (TDS) versus $\mathrm{Na}^{+} /\left(\mathrm{Na}^{+}+\mathrm{Ca}^{2+}\right)$; (b) TDS versus $\mathrm{Cl}^{-} /\left(\mathrm{Cl}^{-}+\mathrm{HCO}_{3}^{-}\right)$.
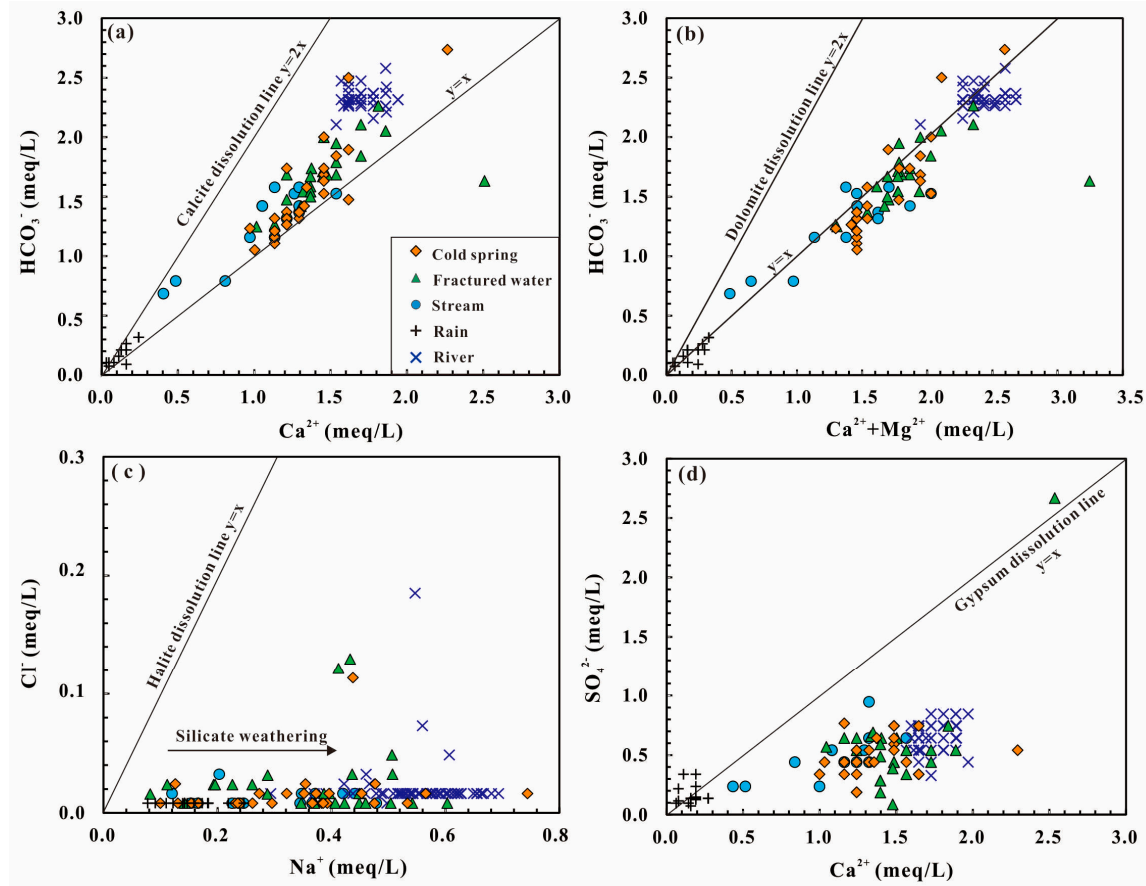

Figure 6. Distributions of ionic ratios in water samples, (a) $\mathrm{HCO}_{3}{ }^{-}$versus $\mathrm{Ca}^{2+}$; (b) $\mathrm{HCO}_{3}{ }^{-}$versus $\mathrm{Ca}^{2+}+\mathrm{Mg}^{2+} ;$ (c) $\mathrm{Cl}^{-}$versus $\mathrm{Na}^{+} ;$(d) $\mathrm{SO}_{4}{ }^{2-}$ versus $\mathrm{Ca}^{2+}$.

If $\mathrm{Na}^{+}$is derived from the dissolution of halite, the $\mathrm{Na}^{+} / \mathrm{Cl}^{-}$molar ratio generally is equal to 1 . However, the $\mathrm{Na}^{+} / \mathrm{Cl}^{-}$molar ratio of water samples are much higher than 1 , implying the excess $\mathrm{Na}^{+}$ 
concentration is derived from silicate weathering (Figure 6c). In addition, the low $\mathrm{Cl}^{-}$concentration

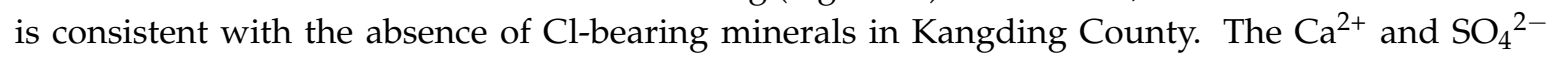
concentrations of groundwater are controlled by gypsum dissolution and precipitation processes, which are shown in Equation (3) below.

$$
\mathrm{CaSO}_{4} \cdot 2 \mathrm{H}_{2} \mathrm{O} \rightleftarrows \mathrm{Ca}^{2+}+\mathrm{SO}_{4}^{2-}+2 \mathrm{H}_{2} \mathrm{O}
$$

In the condition of simple gypsum dissolution and precipitation, the ratio between $\mathrm{Ca}^{2+}$ and $\mathrm{SO}_{4}{ }^{2-}$ would be 1:1. The plots are distinctly below $1: 1$ line in $\mathrm{Ca}^{2+}$ versus $\mathrm{SO}_{4}{ }^{2-}$ diagram (Figure $6 \mathrm{~d}$ ), implying a majority of enriched $\mathrm{Ca}^{2+}$ that would be produced from dissolution of carbonates and silicate minerals. The deficient $\mathrm{SO}_{4}{ }^{2-}$ concentration suggests a weak effect from anthropogenic activity.

The $\mathrm{Ca}^{2+}, \mathrm{Mg}^{2+}, \mathrm{HCO}_{3}{ }^{-}$and $\mathrm{SO}_{4}{ }^{2-}$ would be derived from the dissolution of carbonates and sulfate minerals when the plots follow the $1: 1$ line in the $\left(\mathrm{Ca}^{2+}+\mathrm{Mg}^{2+}\right)$ versus $\left(\mathrm{HCO}_{3}{ }^{-}+\mathrm{SO}_{4}{ }^{2-}\right)$ diagram. Furthermore, the plots above the 1:1 line suggest ion exchange as dominant process (4), while the plots below the 1:1 line indicate existence of reverse ion exchange (5).

$$
\begin{gathered}
\text { Ion exchange: } 2 \mathrm{Na}^{+}-\mathrm{Clay}+\mathrm{Ca}^{2+} \rightarrow 2 \mathrm{Na}^{+}+\mathrm{Ca}^{2+}-\mathrm{Clay}_{2} \\
\text { Reverse Ion exchange: } \mathrm{Ca}^{2+}-\mathrm{Clay}_{2}+2 \mathrm{Na}^{+} \rightarrow \mathrm{Ca}^{2+}+2 \mathrm{Na}^{+}-\mathrm{Clay}
\end{gathered}
$$

Most samples plotted above the 1:1 line of $\left(\mathrm{HCO}_{3}{ }^{-}+\mathrm{SO}_{4}{ }^{2-}\right) /\left(\mathrm{Ca}^{2+}+\mathrm{Mg}^{2+}\right)$ ratio (Figure 7). The $\left(\mathrm{Ca}^{2+}+\mathrm{Mg}^{2+}\right)$ concentrations are slightly deficient compared with $\mathrm{HCO}_{3}{ }^{-}$and $\mathrm{SO}_{4}{ }^{2-}$. As the dominated cation, $\mathrm{Ca}^{2+}$ is more preferable than $\mathrm{Mg}^{2+}$. Considering Equations (4) and (5), we can assume the deficiency of $\mathrm{Ca}^{2+}$ is due to ion exchange process that is a significant result from silicate weathering.

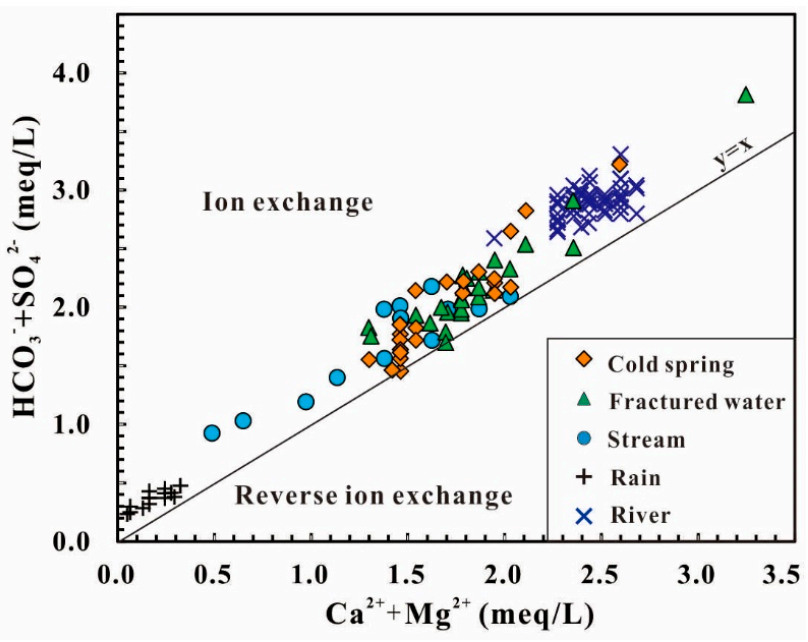

Figure 7. $\mathrm{HCO}_{3}{ }^{-}+\mathrm{SO}_{4}{ }^{2-}$ versus $\mathrm{Ca}^{2+}+\mathrm{Mg}^{2+}$ diagram.

\subsubsection{Mineral Saturations}

During the process of water-rock interaction, the mineral equilibrium calculation can reflect the thermodynamic process of natural water system [12,13]. Moreover, SI gives an insight of the reactivity of minerals. Herein, SI values of water samples were calculated using Phreeqc 3 software, based on Equation (6) below:

$$
\mathrm{SI}=\log (\mathrm{IAP}) / \mathrm{K}
$$

where IAP is the Ion Activity Product, $\mathrm{K}$ is the equilibrium constant. Positive SI values (SI $>0$ ) show mineral oversaturation and precipitation, whereas negative SI values $(\mathrm{SI}<0)$ imply minerals under saturation and dissolution. The calculated results for surface water and groundwater samples 
are listed in Table S1. Most water samples yielded similar SI calculated results as follows: calcite and dolomite were slightly undersaturated to oversaturated, gypsum was weakly under saturated, and halite was strongly under saturated (Figure 8). Those calculated results propose that water-rock interaction had not reached to equilibrium yet in the surface water and groundwater of Kangding County. In Equation (3), abundant $\mathrm{Ca}^{2+}$ released from the dissolution of calcite will hamper the solubility of $\mathrm{CaSO}_{4} \cdot 2 \mathrm{H}_{2} \mathrm{O}$, leading to the under saturation of gypsum. The absence of $\mathrm{Cl}^{-}$-bearing minerals would account for the low SI values of halite. Due to the positive correlation between SI values and TDS, the hydrochemical characteristics of surface water and groundwater were mainly determined by the dissolution and precipitation of minerals from bedrocks.
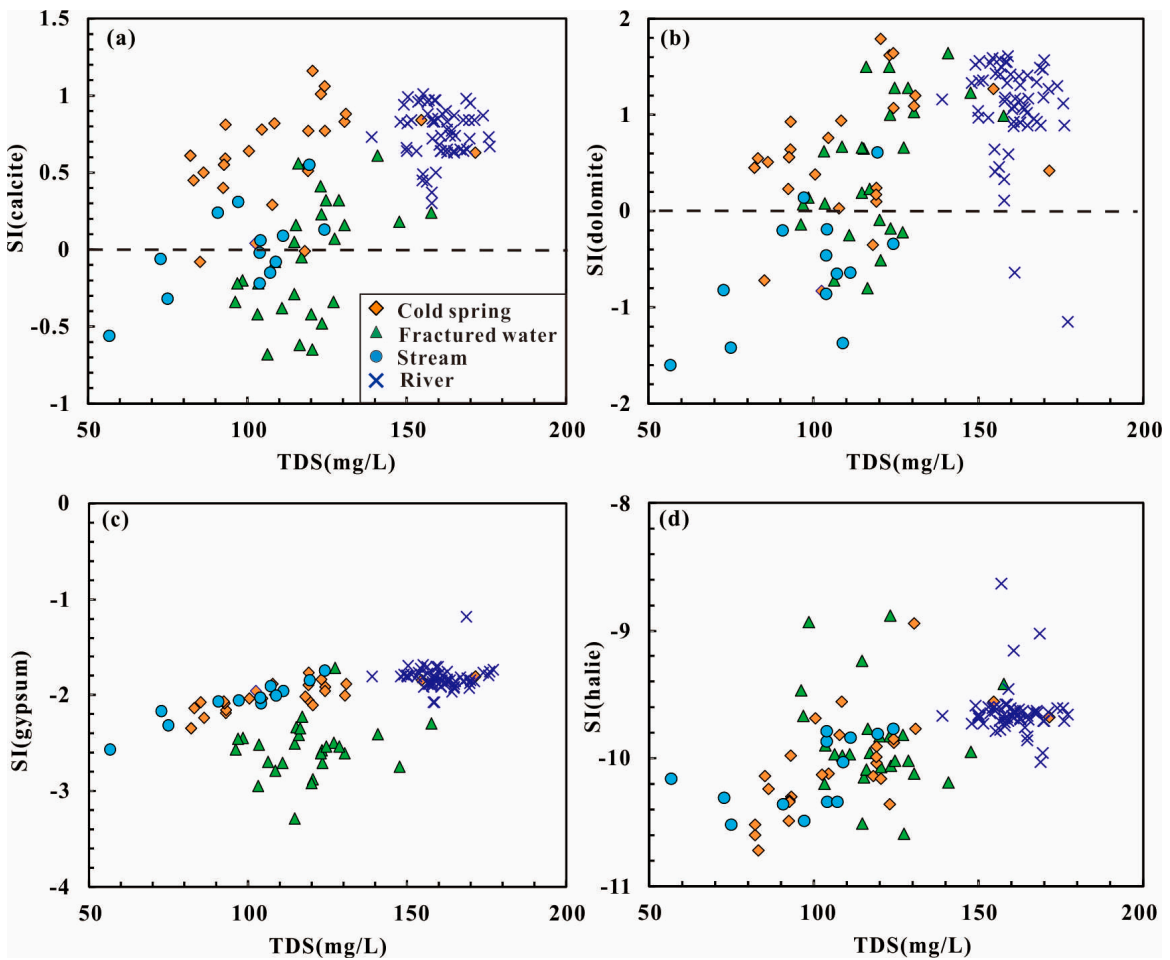

Figure 8. Saturation index (SI) versus total dissolved solids (TDS) (mg/L) diagrams. (a) SI (calcite); (b) SI (dolomite); (c) SI (gypsum), and (d) SI (halite).

\subsubsection{Multivariate Statistical Analysis}

The correlations applied to the eight variables ( $\mathrm{pH}$, TDS and major ions) shed light on the relationships among those variables and water-rock interaction controlling the hydrochemical parameters [1-3]. The values of $\mathrm{R}>0.75$ and $0.75>\mathrm{R}>0.50$ suggested strong and moderate correlations between the hydrochemical parameters, respectively [11-13]. To avoid the error triggered by different unite, all variables were treated by log-ratio transforms prior to multivariate statistical analysis. The results of correlation analysis are listed in Table 1 . TDS had good consistency with $\mathrm{Ca}^{2+}, \mathrm{Mg}^{2+}$, and $\mathrm{HCO}_{3}{ }^{-}$. $\mathrm{Ca}^{2+}$ showed great consistency with $\mathrm{Mg}^{2+}$, representing the aquifer system of carbonates. Meanwhile, $\mathrm{pH}$ had moderate and positive correlation with carbonates elements $\left(\mathrm{Ca}^{2+}, \mathrm{Mg}^{2+}\right.$ and $\left.\mathrm{HCO}_{3}{ }^{-}\right)$, indicating the chemical equilibrium between $\mathrm{pH}$ and dissolution of carbonates. However, the correlation between $\mathrm{Ca}^{2+}$, $\mathrm{Mg}^{2+}$ and $\mathrm{HCO}_{3}{ }^{-}$was not as high as expected, against simple sources from the dissolution of carbonates. In addition, the moderate positive correlation between $\mathrm{Ca}^{2+}, \mathrm{Mg}^{2+}$ and $\mathrm{Na}^{+}$revealed the possibility of ion exchange processes from the dissolution of silicate minerals. Hence, it is believable the dissolution of carbonate and silicate minerals dominated the major anions and cations of water in the Kangding area. Additionally, moderate consistency occurring between $\mathrm{Ca}^{2+}$ and $\mathrm{SO}_{4}{ }^{2-}$ indicated the dissolution 
of gypsum. The $\mathrm{Na}^{+}-\mathrm{Cl}^{-}$pair had weak positive correlation, suggesting that they are not considerably affected by the simple dissolution of halite.

Table 1. Correlation matrix of the species in water samples.

\begin{tabular}{cccccccccc}
\hline Correlation & $\mathbf{p H}$ & $\mathbf{T D S}$ & $\mathbf{K}^{+}$ & $\mathbf{N a}^{+}$ & $\mathrm{Ca}^{2+}$ & $\mathbf{M g}^{2+}$ & $\mathrm{Cl}^{-}$ & $\mathbf{S O}_{4}{ }^{2-}$ & $\mathbf{H C O}_{3}{ }^{-}$ \\
\hline $\mathrm{pH}$ & 1 & & & & & & & & \\
$\mathrm{TDS}$ & 0.340 & 1 & & & & & & & \\
$\mathrm{~K}^{+}$ & 0.168 & 0.359 & 1 & & & & & & \\
$\mathrm{Na}^{+}$ & 0.268 & 0.662 & 0.601 & 1 & & & & & \\
$\mathrm{Ca}^{2+}$ & 0.304 & 0.902 & 0.139 & 0.419 & 1 & & & & \\
$\mathrm{Mg}^{2+}$ & 0.355 & 0.780 & 0.181 & 0.383 & 0.617 & 1 & & & \\
$\mathrm{Cl}^{-}$ & 0.084 & 0.281 & 0.015 & 0.204 & 0.256 & 0.277 & 1 & & \\
$\mathrm{SO}_{4}{ }^{2-}$ & 0.182 & 0.707 & 0.261 & 0.516 & 0.512 & 0.555 & 0.144 & 1 & \\
$\mathrm{HCO}_{3}{ }^{-}$ & 0.288 & 0.924 & 0.357 & 0.644 & 0.874 & 0.751 & 0.252 & 0.435 & 1 \\
\hline
\end{tabular}

Hydrochemical parameters including $\mathrm{pH}$ and major ions were used for principal component analysis, which is helpful for tracing the sources of those ions [16,17]. The results of principal component analysis includes eigenvalue, percentage of variance, cumulative percentage of variance, and the factor loading, presented in Table 2. Scree plots for groundwater samples showed a distinct change of slop after the third factor (Figure 9). Using the Kaiser Criterion and scree plot, three principle components (PCs) of eigenvalues greater than 1 have been obtained, accounting for the total variance of $74.456 \%$. The PC1 was responsible for $50.229 \%$ of total variance and has a strong loading of TDS, $\mathrm{Na}^{+}, \mathrm{Ca}^{2+}, \mathrm{Mg}^{2+}$, and $\mathrm{HCO}_{3}{ }^{-}$. This factor indicates the general trend of hydrochemcial characteristics, probably dominated by the dissolution of carbonates and silicate minerals. The PC2 explained $12.622 \%$ of total variance and has medium positive loading of $\mathrm{Ca}^{2+}$ and $\mathrm{SO}_{4}{ }^{2-}$. As such, PC2 could be linked to the dissolution of gypsum. PC3 contributed only $11.604 \%$ of the variances, and it only included a single major species, $\mathrm{Cl}^{-}$, which was related to the anthropogenic activity or limited dissolution of halite.
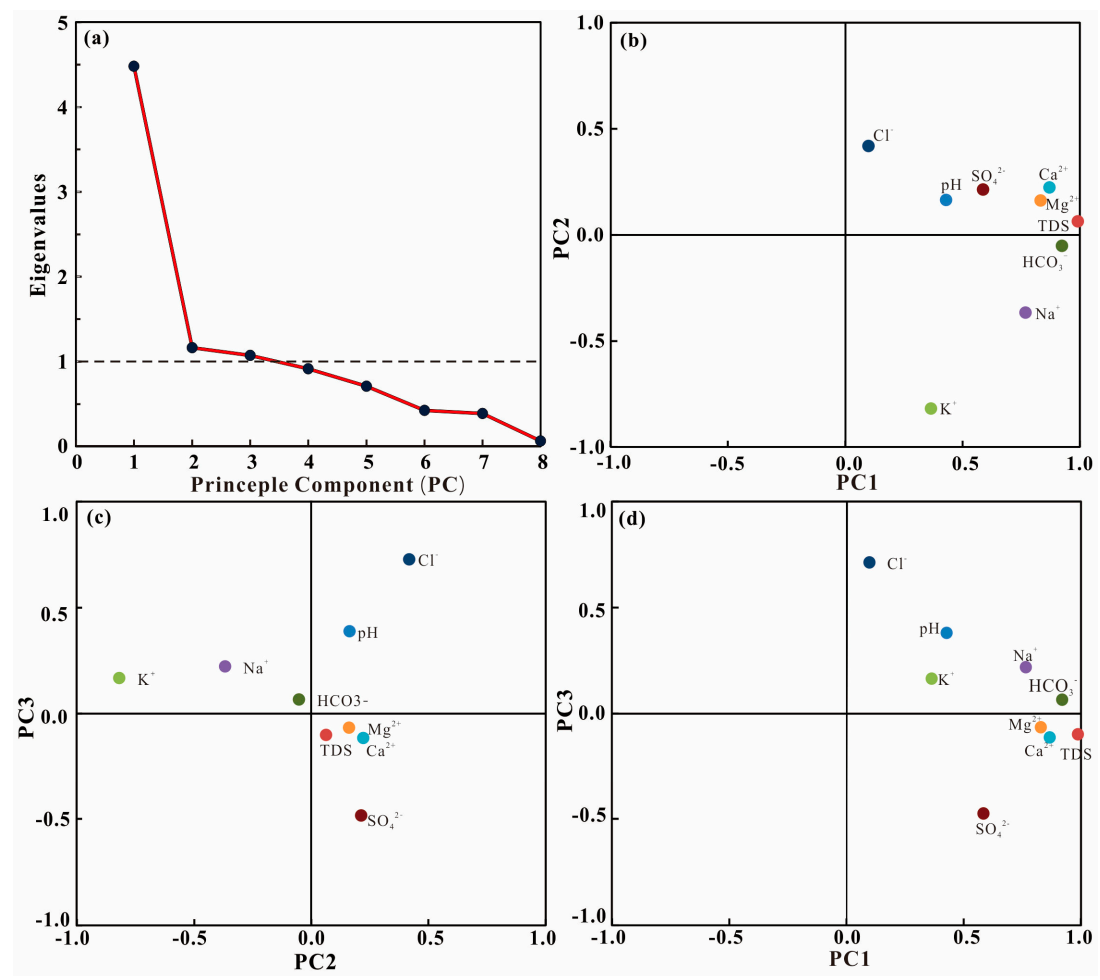

Figure 9. (a) Scree plot; Factor loadings for (b) PC1 and PC2; (c) PC2 and PC3; (d) PC1 and PC3. 
Table 2. Factor loadings and eigenvalues of the eight extracted factors.

\begin{tabular}{cccc}
\hline Scaled Coordinates & PC1 & PC2 & PC3 \\
\hline $\mathrm{pH}$ & 0.428 & 0.164 & 0.393 \\
$\mathrm{TDS}$ & 0.988 & 0.064 & -0.100 \\
$\mathrm{~K}^{+}$ & 0.364 & -0.819 & 0.170 \\
$\mathrm{Na}^{+}$ & 0.766 & -0.367 & 0.226 \\
$\mathrm{Ca}^{2+}$ & 0.868 & 0.223 & -0.115 \\
$\mathrm{Mg}^{2+}$ & 0.830 & 0.162 & -0.066 \\
$\mathrm{Cl}^{-}$ & 0.098 & 0.419 & 0.735 \\
$\mathrm{SO}_{4}{ }^{2-}$ & 0.585 & 0.214 & -0.488 \\
$\mathrm{HCO}_{3}{ }^{-}$ & 0.921 & -0.052 & 0.068 \\
Eigenvalues & 4.521 & 1.136 & 1.044 \\
Variance (\%) & 50.229 & 12.622 & 11.604 \\
Cumulative (\%) & 50.229 & 62.852 & 74.456 \\
\hline
\end{tabular}

\subsection{Mixing Model of Groundwater and Thermal Water}

The main anions $\left(\mathrm{Cl}^{-}, \mathrm{SO}_{4}{ }^{2-}\right.$ and $\left.\mathrm{HCO}_{3}{ }^{-}\right)$have been used to identify the mixture between thermal and cold water [32]. The majority of thermal water samples were distributed on the field of peripheral water (Figure 10a), indicative of the involvement of cold water. Furthermore, the Na-K-Mg ternary diagram shows that all thermal water samples were typical of immature water [32] (Figure 10b), as well as relatively deficient saturated indices of different minerals in Table S1. Giggenbach and Goguel (1989) suggested the low equilibrium of thermal water was attributed to the dilution and mixing of surficial cold water [33]. The water-rock equilibrium at different temperatures was interpreted using the $10 \mathrm{Mg}^{2+} /\left(10 \mathrm{Mg}^{2+}+\mathrm{Ca}^{2+}\right)$ versus $10 \mathrm{~K}^{+} /\left(10 \mathrm{~K}^{+}+\mathrm{Na}^{+}\right)$diagram. In Figure 10c, all thermal water samples were plotted above the curved line of the full equilibrium, yielding the recharge of cold water. Hence, we could infer that thermal water was typical of immature water, involved with cold water.
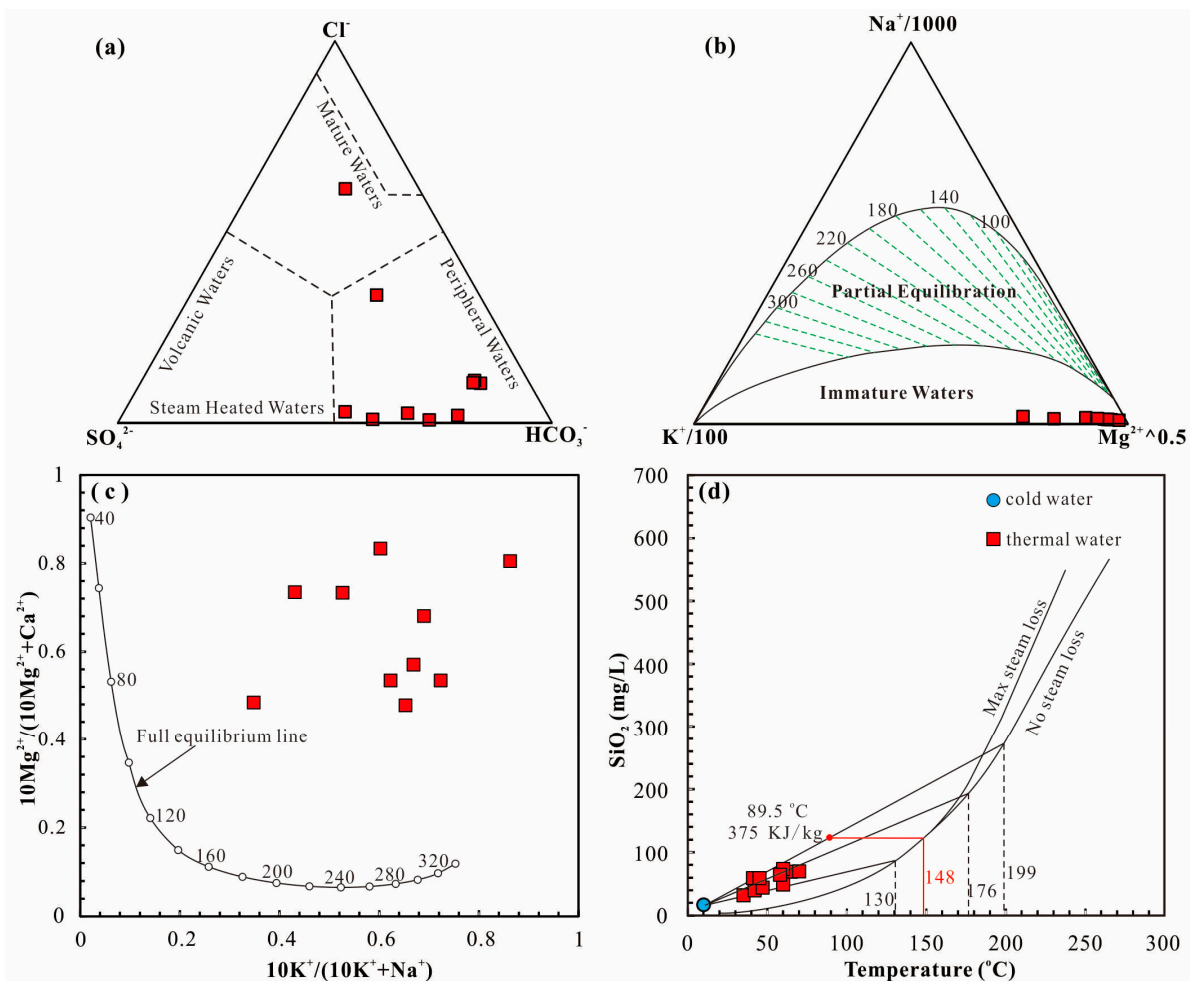

Figure 10. (a) Giggenbach $\mathrm{Cl}^{-}-\mathrm{SO}_{4}{ }^{2-}-\mathrm{HCO}_{3}{ }^{-}$and (b) Na-K-Mg ternary diagrams; (c) $\mathrm{Mg}^{2+} /\left(\mathrm{Mg}^{2+}+\mathrm{Ca}^{2+}\right)$ versus $10 \mathrm{~K}^{+} /\left(10 \mathrm{~K}^{+}+\mathrm{Na}^{+}\right)$diagram; (d) $\mathrm{SiO}_{2}$ versus temperature diagram. Silica concentration of cold water is the average values of groundwater samples in Table S1. 
To evaluate the original temperature of thermal water and mixing ratio of cold water, the field temperatures and silica concentration of thermal and cold water have been extensively carried out $[34,35]$, based on the Equations (7) and (8) below:

$$
\begin{gathered}
\mathrm{S}_{\mathrm{c}} \mathrm{x}+\mathrm{S}_{\mathrm{h}}(1-\mathrm{x})=\mathrm{S}_{\mathrm{s}} \\
\mathrm{SiO}_{2 \mathrm{c}}+\mathrm{SiO}_{2 \mathrm{~h}}(1-\mathrm{x})=\mathrm{SiO}_{2 \mathrm{~s}}
\end{gathered}
$$

where $S_{c}$ is the enthalpy of cold water, $S_{h}$ is the initial enthalpy of deep thermal water, $S_{s}$ is the last enthalpy of thermal water, $\mathrm{SiO}_{2 \mathrm{c}}$ is the $\mathrm{SiO}_{2}$ concentration of cold water, $\mathrm{SiO}_{2 \mathrm{~h}}$ is the initial $\mathrm{SiO}_{2}$ content of deep thermal water, and $\mathrm{SiO}_{2 \mathrm{~s}}$ is the $\mathrm{SiO}_{2}$ concentration of thermal water. Founier and Truesdell (1974) proposed a graphical way to obtain the two unknowns [34]. In Figure 11, red and blue curves are drawn, and their intersections represent the mixing portion of cold water and estimated reservoir temperature. Based on the results from Figure 11, we can infer the original temperature and mixing ratios were $112-195^{\circ} \mathrm{C}$ and $0.56-0.79$, respectively. Moreover, a silicon-enthalpy graphic method has been conducted to estimate the reservoir temperature of mixing water [33]. It was assumed that no silica deposition existed before or after mixing and that quartz determines the solubility of silica in thermal water. A straight line connecting the points of cold water and points of thermal water intersect with the solubility curve for quartz at a point that gives the silica content and enthalpy value of thermal water in the condition of no steam loss (Figure 10d) [35]. Moreover, the intersection points with the "No steam loss" line also suggested the mixing origin. Those intersection points and cold water samples were regarded as the end member for initial thermal water and cold water, indicative of the reservoir temperature and mixing ratios. If steam separation took place at $89.5^{\circ} \mathrm{C}$ (local boiling temperature), the calculated reservoir temperature is $148^{\circ} \mathrm{C}$. When no steam loss occurs, the reservoir temperatures range from 130 to $199{ }^{\circ} \mathrm{C}$, while mixing ratio of cold water is estimated to be $30-40 \%$, consistent with the calculated results from silica-enthalpy formula. Hence, the calculated results should be reliable. It is noteworthy that the estimated reservoir temperatures were much greater than the discharge temperature, suggesting that plenty of cold-water recharge occurred in a surficial place.
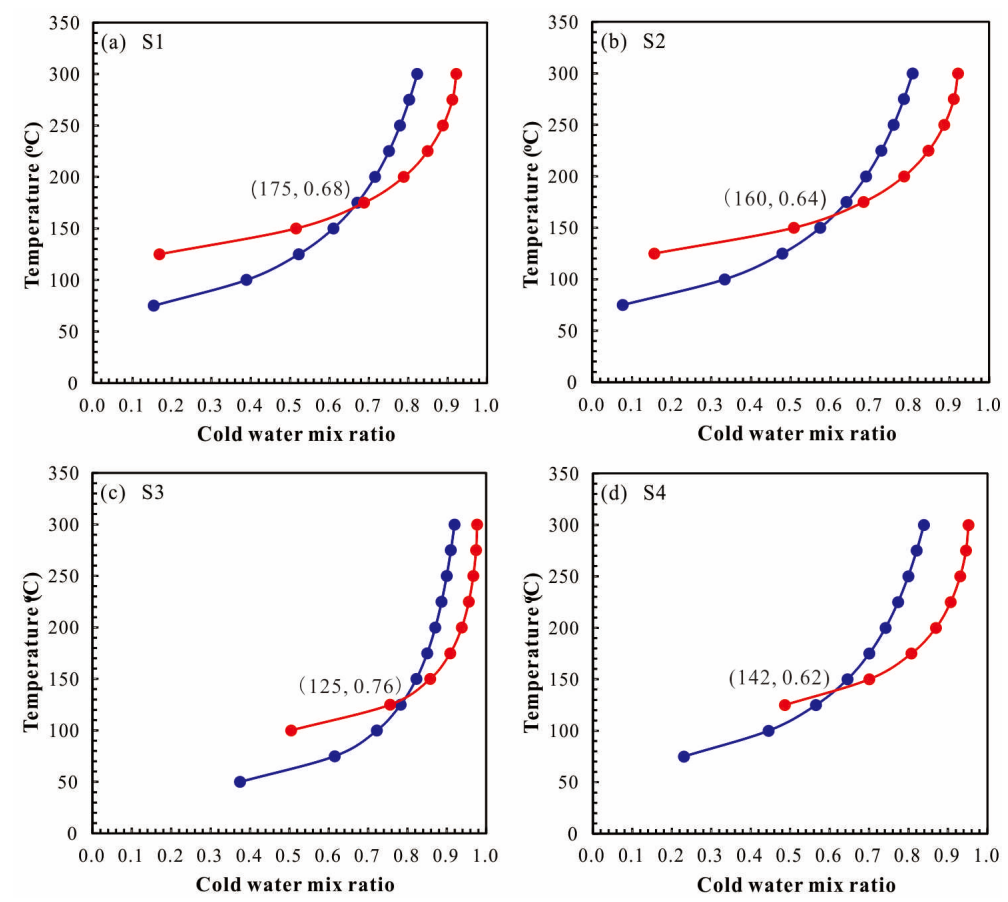

Figure 11. Cont. 

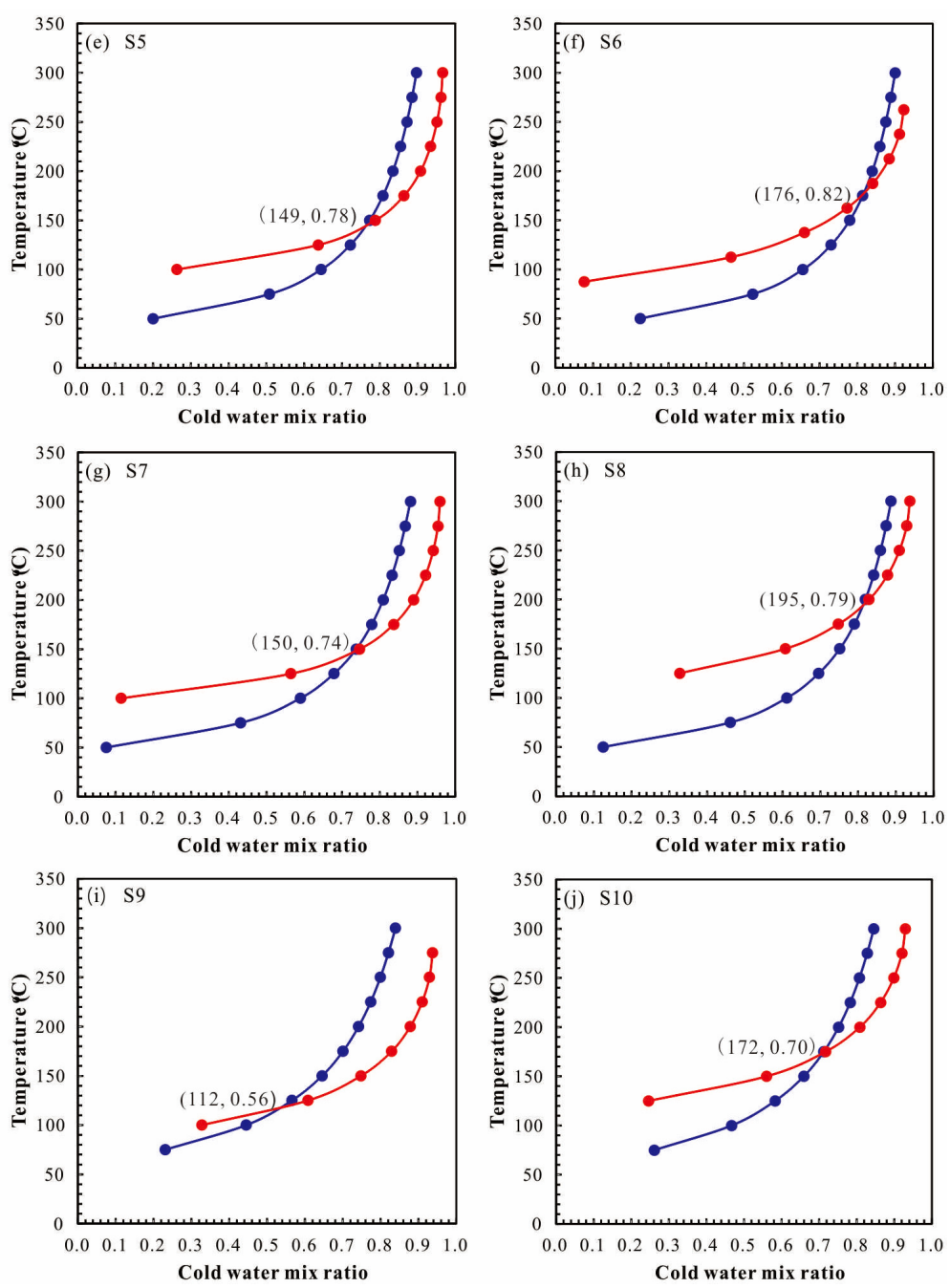

Figure 11. Relations between fraction of cold water and temperature in the mixing model. Blue curve $=$ enthalpy, red curve $=$ silica.

\subsection{Evaluation for $\delta D$ and $\delta^{18} O$ Isotopes}

The results of $\delta \mathrm{D}$ and $\delta^{18} \mathrm{O}$ isotopes from surface water (river), groundwater (cold spring and fractured water) and thermal water are listed in Table S2. The $\delta \mathrm{D}$ and $\delta^{18} \mathrm{O}$ values of surface water and groundwater in study area had a similar range of -75.39 to $-86.47 \%$ ond -11.01 to $-12.47 \%$, while $\delta \mathrm{D}$ and $\delta^{18} \mathrm{O}$ values of thermal water largely varied from -78.77 to $-113.27 \%$, and -10.04 to $-16.13 \%$, respectively. Compared to thermal water, surface water and groundwater had richer $\delta \mathrm{D}$ values. Most samples were distributed around the Global Meteoric Water Line (GMWL) (solid line: $\delta \mathrm{D}=8 \times \delta^{18} \mathrm{O}+10 \%$ ) [36] and Local Meteoric Water Line (LMWL) (dash line: $\delta \mathrm{D}=9.4 \times \delta^{18} \mathrm{O}+28.5 \%$ ) [37], indicating a meteoric origin (Figure 12). It is generally acceptable that $\delta \mathrm{D}$ and $\delta^{18} \mathrm{O}$ values will decrease corresponding to changing elevation, due to topographic precipitation [38]. Hence, using the recharge altitude calculated by $\delta \mathrm{D}$ and $\delta^{18} \mathrm{O}$ values, we can constrain the general recharge area of those water samples. In the study area, the ratio between $\delta \mathrm{D}$ and altitude has been suggested in $-2.24 \%$ o per $100 \mathrm{~m}$ [37]. The calculated results presented the recharge altitudes of surface water and groundwater as 1059-1517 $\mathrm{m}$. The recharge area of thermal water was located in a large variation of 2199-5302 m, much higher than those of surface water and groundwater. Therefore, we can propose that thermal water was recharged by precipitation from high elevation, while surface water and groundwater were recharged by precipitation from low elevation. Moreover, 
obvious $\delta^{18} \mathrm{O}$ drift in Figure 12 suggests that thermal water experienced remarkable and prolonged water-rock interaction during the deep circulation, corresponding to high TDS and concentrations of major ions.

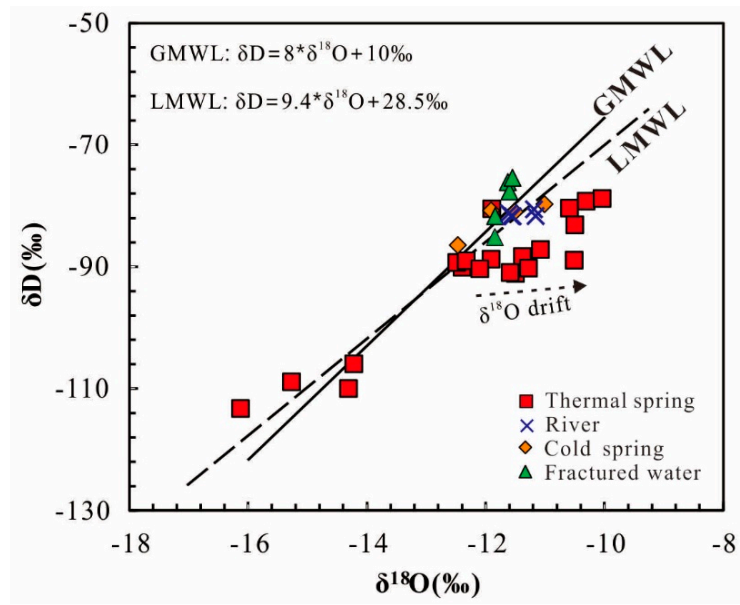

Figure 12. Variation of $\delta \mathrm{D}$ and $\delta^{18} \mathrm{O}$ in groundwater and thermal springs associated with Global Meteoric Water Line (GMWL) [36] and Local Meteoric Water Line (LMWL) [37].

\subsection{Hydrological Conceptual Model of Natural Water System}

Generally speaking, the concentrations of radiogenic elements (e.g., U, Th, K) in granitic rocks are closely related to thermal source of the Earth, whose radioactive decay can generate great heat production [39]. Mount. Gongga, as a young batholith uplift during Mioncene, preserves quite high amounts of thermal energy [26]. Meanwhile, a previous study proposed that deep magmatic activity is occurring in the Kangding area, which could be another potential thermal source [25]. Moreover, the Xianshuihe fault provides a beneficial circulating conduit for thermal water. Combined the hydrochemical and $\delta \mathrm{D}$ and $\delta^{18} \mathrm{O}$ isotopes, we can briefly conclude the formation of thermal springs as below: meteoric water was infiltrated and mixed with magmatic water in a deep place. Then, meteoric water was heated by radioactive decay and deep magmatic source. During the circulation, $\mathrm{Cl}^{-}$was derived from inputs of magmatic water, while $\mathrm{SO}_{4}{ }^{2-}$ probably originated from the dissolution of sulfide minerals (e.g., pyrite) in granite. When thermal water reaches shallow location, the mixture between thermal water and cold water would occur through fractures (Figure 13).

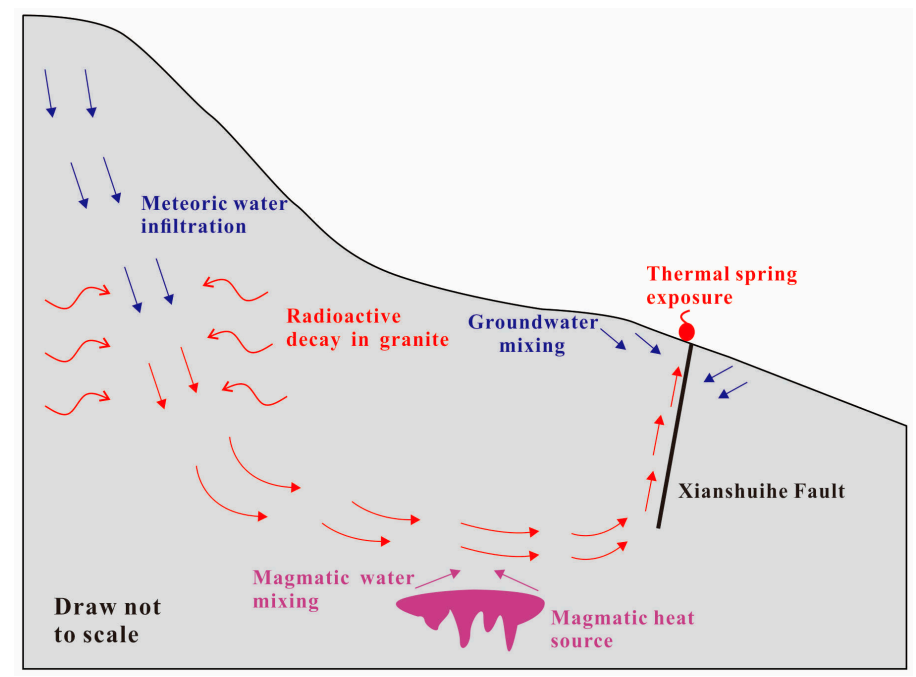

Figure 13. Conceptual model of thermal spring in Kangding County. 
Based on the aforementioned geological setting, hydrochemical and isotopic analyses above, a hydrological conceptual model for the natural water system (surface water, groundwater, and thermal water) in Kangding County was constructed (Figure 14). A joint study of the ratio of major ions, geochemical modelling, and multivariate statistical analysis concluded that hydrochemical processes of surface water and groundwater were dominated by the dissolution of carbonates and silicate minerals, corresponding to the limestone and granite aquifers in Kangding County. $\delta \mathrm{D}$ and $\delta^{18} \mathrm{O}$ isotopic results showed high recharge elevations of 2199-5302 m, implying the potential recharge area from Mount. Gongga $(7556 \mathrm{~m})$ and adjacent mountain areas. Based on the concentrations of major ions and $\mathrm{SiO}_{2}$, thermal water samples were identified as immature water, with a cold-water mixing ratio of $0.56-0.79$. Meanwhile, the discharge temperatures in surficial places were much lower than the estimated reservoir temperatures, indicative of large involvements of cold water. The N-S Xianshuihe fault direction and adjacent NNE-striking secondary fractures are responsible for vertical and lateral flow in natural water system. Herein, it is reasonable that abundant groundwater penetrating through those fractures recharges the thermal aquifer system. Additionally, the favorable hydraulic connection between surface water and groundwater has been determined by their similar hydrochemical and $\delta \mathrm{D}-\delta^{18} \mathrm{O}$ isotopic characteristics. Therefore, we can conclude the Xianshuihe fault provides a deep channel for upwelling of thermal water, while those fractures are the ideal chamber for the surface water-groundwater interaction and recharge to thermal water in a surficial place.

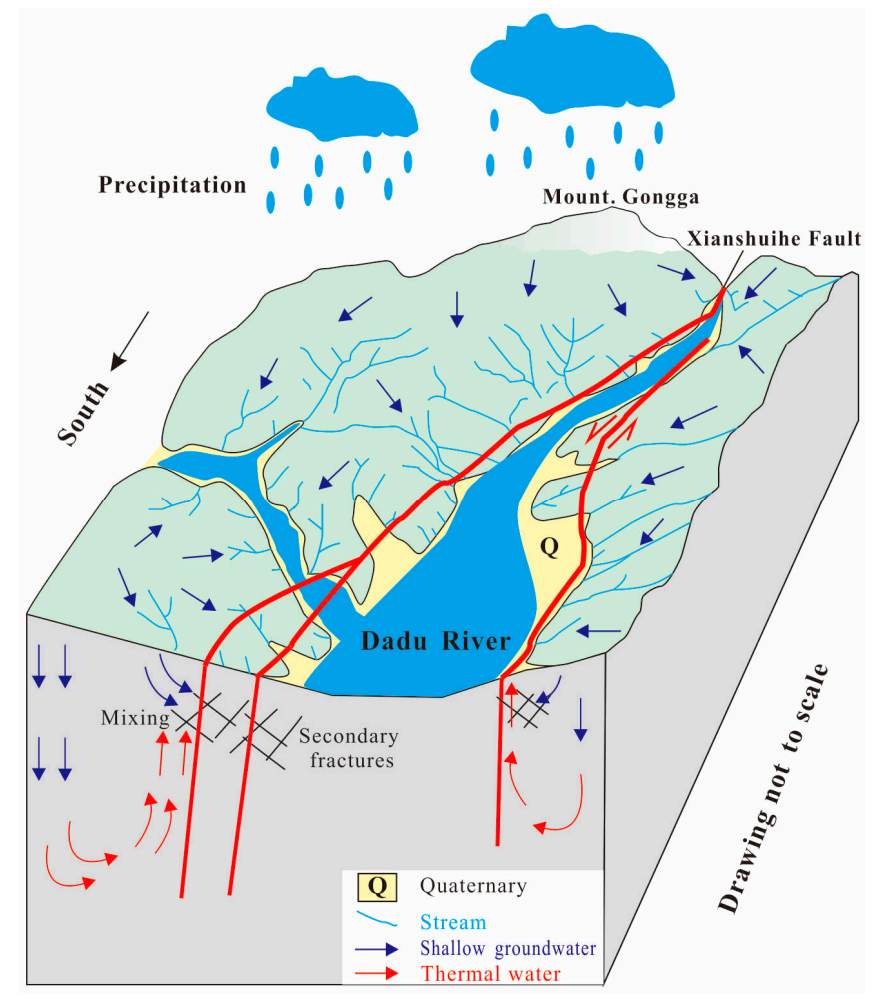

Figure 14. Hydrological conceptual model of natural water system in Kangding County.

\section{Conclusions}

Integrated assessments of variable data based on hydrochemical analysis, multivariate statistics and geochemical modelling, provide the basis for comprehensive understanding of natural water systems in Kangding County, which can be summarized as follows:

1. Surface water and groundwater are dominated by $\mathrm{Ca}-\mathrm{HCO}_{3}$ type, while thermal water belongs to $\mathrm{Ca}-\mathrm{HCO}_{3}$ and $\mathrm{Na}-\mathrm{Cl}-\mathrm{SO}_{4}$ types. 
2. Correlations of major ions, multivariate statistical analysis, and saturation index indicated that the dissolution of carbonates and silicate minerals were the main hydrochemical processes affecting chemical components of natural water systems in limestone and granite aquifers. Detailed effects of anthropogenic activity on hydrochemistry have yet to be further investigated by more minor elements in the future.

3. Thermal water is typical of immature water that is involved with a cold-water fraction of 0.56-0.79. The estimated reservoir temperatures have a range of 130 to $199^{\circ} \mathrm{C}$.

4. $\delta \mathrm{D}$ and $\delta^{18} \mathrm{O}$ isotopes revealed a meteoric origin of hydrological system. Thermal water is recharged by precipitation from high elevation, while surface water and groundwater are recharged by precipitation from low elevation.

5. The Xianshuihe fault is the rising channel for thermal water, while adjacent secondary fractures provide the chambers for groundwater-surface water interaction and groundwater recharging with thermal water.

Supplementary Materials: The following are available online at www.mdpi.com/2073-4441/10/1/80/s1, Table S1: Hydrochemical composition of water samples, Table S2: $\delta \mathrm{D}$ and $\delta^{18} \mathrm{O}$ isotopes of representative water samples.

Acknowledgments: We thank anonymous reviewers and the Editor-in-Chief for their constructive comments. We thank Jing Yu and Ziwen Hu at the State Key Laboratory of Geohazard Prevention and Geo-environment Protection, Chengdu University of Technology for their assistance and helpful discussions. We are also grateful to the English editing by Conor O'Sullivan.

Author Contributions: Yunhui Zhang, Mo Xu, and Xiao Li conceived and designed the research direction. Yunhui Zhang wrote the paper. Jihong Qi, Qiang Zhang and Leilei Yu did the field work and collected water samples; Jian Guo and Rui Zhao performed the experiments and analyzed the data. All authors read and approved the final manuscript.

Conflicts of Interest: The authors declare no conflict of interest.

\section{References}

1. Rakotondrabe, F.; Ngoupayou, J.R.N.; Mfonka, Z.; Rasolomanana, E.H.; Abolo, A.J.N.; Ako, A.A. Water quality assessment in the Betare-Oya gold mining area (East-Cameroon): Multivariate Statistical Analysis approach. Sci. Total Environ. 2018, 610-611, 831-844. [CrossRef] [PubMed]

2. Kazakis, N.; Matta, C.; Pavlou, A.; Patrikaki, O.; Voudouris, K. Multivariate statistical analysis for the assessment of groundwater quality under different hydrogeological regimes. Environ. Earth Sci. 2017, 76, 349-361. [CrossRef]

3. Hamzah, Z.; Aris, A.Z.; Ramli, M.F.; Juahir, H.; Narany, T.S. Groundwater quality assessment using integrated geochemical methods, multivariate statistical analysis, and geostatistical technique in shallow coastal aquifer of Terengganu, Malaysia. Arab. J. Geosci. 2017, 10, 49-65. [CrossRef]

4. Xiao, Y.; Gu, X.M.; Yin, S.Y.; Pan, X.Y.; Shao, J.L.; Cui, Y.L. Investigation of Geochemical Characteristics and Controlling Processes of Groundwater in a Typical Long-Term Reclaimed Water Use Area. Water 2017, 9, 800. [CrossRef]

5. Gu, X.M.; Zhang, Q.L.; Cui, Y.L.; Shao, J.L.; Xiao, Y.; Zhang, P.; Liu, J.X. Hydrogeochemistry and Genesis Analysis of Thermal and Mineral Springs in Arxan, Northeastern China. Water 2017, 9, 61. [CrossRef]

6. Wu, X.; Zheng, Y.; Zhang, J.; Wu, B.; Wang, S.; Tian, Y.; Li, J.G.; Meng, X. Investigating Hydrochemical Groundwater Processes in an Inland Agricultural Area with Limited Data: A Clustering Approach. Water 2017, 9, 723. [CrossRef]

7. Pasvanoğlu, S.; Çelik, M. A conceptual model for groundwater flow and geochemical evolution of thermal fluids at the Kizilcahamam geothermal area, Galatian volcanic Province. Geothermics 2018, 71, 88-107. [CrossRef]

8. Yurteri, C.; Simsek, S. Hydrogeological and hydrochemical studies of the Kaman-Savcili-Büyükoba (Kirsehir) geothermal area, Turkey. Geothermics 2017, 65, 99-112. [CrossRef]

9. Yang, P.H.; Cheng, Q.; Xie, S.Y.; Wang, J.L.; Chang, L.R.; Yu, Q.; Zhan, Z.J.; Chen, F. Hydrogeochemistry and geothermometry of deep thermal water in the carbonate formation in the main urban area of Chongqing, China. J. Hydrol. 2017, 549, 50-61. [CrossRef] 
10. Wang, X.C.; Zhou, X.; Zheng, Y.H.; Song, C.; Long, M.; Chen, T.; Ren, Z.H.; Yang, M.L.; Li, X.L.; Guo, J. Hydrochemical characteristics and mixing behavior of thermal springs along the Bijiang River in the Lanping basin of China. Environ. Earth Sci. 2017, 76, 487-505. [CrossRef]

11. Tziritis, E.P.; Datta, P.S.; Barzegar, R. Characterization and Assessment of Groundwater Resources in a Complex Hydrological Basin of Central Greece (Kopaida basin) with the Joint Use of Hydrogeochemical Analysis, Multivariate Statistics and Stable Isotopes. Aquat. Geochem. 2017, 23, 271-298. [CrossRef]

12. Singh, C.K.; Kumar, A.; Shashtri, S.; Kumar, A.; Kumar, P.; Mallick, J. Multivariate statistical analysis and geochemical modeling for geochemical assessment of groundwater of Delhi, India. J. Geochem. Explor. 2017, 175, 59-71. [CrossRef]

13. Liu, P.; Hoth, N.; Drebenstedt, C.; Sun, Y.J.; Xi, Z.M. Hydro-geochemical paths of multi-layer groundwater system in coal mining regions-Using multivariate statistics and geochemical modeling approaches. Sci. Total Environ. 2017, 601-602, 1-14. [CrossRef] [PubMed]

14. Gil-Márquez, J.M.; Barberá, J.A.; Mudarra, B.A.M. Hydrological and geochemical processes constraining groundwater salinity in wetland areas related to evaporitic (karst) systems. A case study from Southern Spain. J. Hydrol. 2017, 544, 538-554. [CrossRef]

15. Wu, J.H.; Li, P.Y.; Qian, H.; Duan, Z.; Zhang, X.D. Using correlation and multivariate statistical analysis to identify hydrogeochemical processes affecting the major ion chemistry of waters: A case study in Laoheba phosphorite mine in Sichuan, China. Arab. J. Geosci. 2013, 7, 3973-3982. [CrossRef]

16. Kumar, M.S.; Dhakate, R.; Yadagiri, G.; Reddy, K.S. Principal component and multivariate statistical approach for evaluation of hydrochemical characterization of fluoride-rich groundwater of Shaslar Vagu watershed, Nalgonda District, India. Arab. J. Geosci. 2017, 10, 83-99. [CrossRef]

17. Argamasilla, M.; Barbera, J.A.; Andreo, B. Factors controlling groundwater salinization and hydrogeochemical processes in coastal aquifers from southern Spain. Sci. Total Environ. 2017, 580, 50-68. [CrossRef] [PubMed]

18. Yuan, J.F.; Xu, F.; Deng, G.S.; Tang, Y.Q. Using stable isotopes and major ions to identify hydrogeochemical characteristics of karst groundwater in Xide country, Sichuan Province. Carbonates Evaporites 2017, 1-12. [CrossRef]

19. Papp, D.C.; Cociuba, I.; Baciu, C.; Cozma, A. Origin and Geochemistry of Mine Water and its Impact on the Groundwater and Surface Running Water in Post-mining Environments: Zlatna Gold Mining Area (Romania). Aquat. Geochem. 2017, 23, 247-270. [CrossRef]

20. Wang, S.Q.; Liu, Z.; Shao, J.L. Hydrochemistry and H-O-C-S Isotopic Geochemistry Characteristics of Geothermal Water in Nyemo-Nagqu, Tibet. Acta Geol. Sin. 2017, 91, 644-657. [CrossRef]

21. Tiwari, S.K.; Rai, S.K.; Bartarya, S.K.; Gupta, A.K.; Negi, M. Stable isotopes $\left(\delta^{13} C_{D I C}, \delta D, \delta \delta^{18} \mathrm{O}\right)$ and geochemical characteristics of geothermal springs of Ladakh and Himachal (India): Evidence for $\mathrm{CO}_{2}$ discharge in northwest Himalaya. Geothermics 2016, 64, 314-330. [CrossRef]

22. Sun, Z.; Ma, R.; Wang, Y.X.; Hu, Y.L.; Sun, L.J. Hydrogeological and hydrogeochemical control of groundwater salinity in an arid inland basin: Dunhuang Basin, northwestern China. Hydrol. Process. 2016, 30, 1884-1902. [CrossRef]

23. Qi, J.H.; Xu, M.; An, C.J.; Wu, M.L.; Zhang, Y.H.; Li, X.; Zhang, Q.; Lu, G.P. Characterizations of geothermal springs along the Moxi deep fault in the western Sichuan plateau, China. Phys. Earth Planet. Inter. 2017, 263, 12-22. [CrossRef]

24. Luo, J.; Pang, Z.H.; Kong, Y.K.; Wang, Y.C. Geothermal potential evaluation and development prioritization based on geochemistry of geothermal waters from Kangding area, western Sichuan, China. Environ. Earth Sci. 2017, 76, 343-366. [CrossRef]

25. Guo, Q.; Pang, Z.H.; Wang, Y.C.; Tian, J. Fluid geochemistry and geothermometry applications of the Kangding high-temperature geothermal system in eastern Himalayas. Appl. Geochem. 2017, 81, 63-75. [CrossRef]

26. Zhang, Y.Z.; Replumaz, A.; Leloup, P.H.; Wang, G.C.; Bernet, M.; Beek, P.; Paquette, J.L.; Chevalier, M.L. Cooling history of the Gongga batholith: Implications for the Xianshuihe Fault and Miocene kinematics of SE Tibet. Earth Planet. Sci. Lett. 2017, 465, 1-15. [CrossRef]

27. Yan, B.; Lin, A.M. Holocene activity and paleoseismicity of the Selaha Fault, southeastern segment of the strike-slip Xianshuihe Fault Zone, Tibetan Plateau. Tectonophysics 2017, 694, 302-318. [CrossRef] 
28. Parkhurst, D.L.; Appelo, C.A.J. Description of input and examples for PHREEQC version 3: A computer program for speciation, batch-reaction, one-dimensional transport, and inverse geochemical calculations. In Groundwater in Book 6 Modeling Techniques; U.S. Geological Survey: Reston, VA, USA, 2013. Available online: https:/ / pubs.er.usgs.gov/publication/tm6A43 (accessed on 20 October 2017).

29. Piper, A.M. A graphic procedure in the geochemical interpretation of water-analyses. Eos Trans. Am. Geophys. Union 1944, 25, 914-928. [CrossRef]

30. Gibbs, R.J. Mechanisms controlling world water chemistry. Science 1970, 170, 1088-1090. [CrossRef] [PubMed]

31. Adams, S.; Titus, R.; Pietersen, K.; Tredoux, G.; Harris, C. Hydrochemical characteristics of aquifers near Sutherland in the Western Karoo, South Africa. J. Hydrol. 2001, 241, 91-103. [CrossRef]

32. Giggenbach, W.F. Geothermal solute equilibria. Derivation of Na-K-Mg-Ca geoindicators. Geochim. Cosmochim. Acta 1988, 52, 2749-2765. [CrossRef]

33. Giggenbach, W.F.; Goguel, R.L. Collection and analysis of geothermal and volcanic water and gas discharges. In DSIR Report CD 2401, 4th ed.; Pentone: Carlstadt, NJ, USA, 1989; Volume 81. Available online: https:/ / openei.org/wiki/Collection_and_Analysis_of_Geothermal_and_Volcanic_Water_ and_Gas_Discharges (accessed on 1 November 2017).

34. Fournier, R.O. Geochemical indicators of subsurface temperature-part 2, estimation of temperature and fraction of hot water mixed with cold. J. Res. US Geol. Surv. 1974, 2, 263-270.

35. Fournier, R.O. Chemical geothermometers and mixing models for geothermal systems. Geothermics 1977, 5, 41-50. [CrossRef]

36. Craig, H. Isotopic variations in meteoric waters. Science 1961, 133, 1702-1703. [CrossRef] [PubMed]

37. Song, C.L.; Sun, X.Y.; Wang, G.X. A study on precipitation stable isotopes characteristics and vapor sources of the subalpine Gongga Mountain, China. Resour. Environ. Yangtze Basin 2015, 24, 1860-1869, (In Chinese and English Abstract).

38. Blasch, K.W.; Bryson, J.R. Distinguishing sources of ground water recharge by using $\delta^{2} \mathrm{H}$ and $\delta^{18} \mathrm{O}$. Groundwater 2007, 45, 294-308. [CrossRef] [PubMed]

39. Artemieva, I.M.; Thybo, H.; Jakobsen, K.; Sørensen, N.K.; Nielsen, L.S. Heat production in granitic rocks: Global analysis based on a new data compilation GRANITE2017. Earth-Sci. Rev. 2017, 172, 1-26. [CrossRef]

(C) 2018 by the authors. Licensee MDPI, Basel, Switzerland. This article is an open access article distributed under the terms and conditions of the Creative Commons Attribution (CC BY) license (http:/ / creativecommons.org/licenses/by/4.0/). 